\title{
From Geneva to Geneva: A Discourse on Geo-Political Dimension of Conflict in Laos: 1954-1962
}

\author{
Patit Paban Mishra
}

Abstract

During the cold war period, the problem of Laos was exacerbated due to strategic location of Laos and national interest of external actors. The present paper would analyze various ramifications of the conflict in Laos. Beginning from First Indochina War (1946-1954), fate of Laos was linked very closely with that of Vietnam. With the escalation of conflict, a solution to problem of Laos was nowhere in sight. The Geneva Conference of 1954 did not solve the problem. The three major strands in Laos; Pathet Lao, neutralists and the rightists became a constant feature of Lao politics. Both the United States and North Vietnam came into conflict, as they were committed to help their respective allies in Laos, and regarded the other's action in Laos as harmful to their interest in South Vietnam. An agreement on Laos became contingent upon ending the war in Vietnam. The net result of outside intervention was prolongation of conflict in Laos. A solution to Lao conflict was in sight after the Geneva accords of 1962. However, the gradual linkage of the country with the Vietnam War made the solution of dependent upon the outcome of conflict in Vietnam. Laos was going to be embroiled in the Vietnam War and there was no peace in sight unless a solution was there in Vietnam. Laos became a sideshow in Vietnam War.

Keywords: Cold War, Policy of Containment, Negotiated \& Settlement, Peacemaking, Civil War.

\section{Introduction}

The civil war that ranged in Laos during 1960s has many ramifications, both internally as well as externally. Scholars, authors and diplomats have delineated about it. The authors like Roger Hilsman (To Move a Nation: The Politics of Foreign Policy in the Administration of John F. Kennedy, Garden City, 1967), Paul F. Langer and Joseph J. Zasloff (North Vietnam and the Pathet Lao: Partners in the Struggle for Laos, Cambridge: Harvard University Press, 1970) and Hugh Toye (Laos: Buffer State or Battleground, London, 1968) are pro-American in their approach. The Communists were aggravating the problem in Laos. On the other hand, the view point of Phoumi Vongvichit ( Laos and the Victorious Struggle of the Lao People against U.S. Neo-Colonialism, NLHS publications, 1969) is blatantly anti-American and pro-Communist. As usual, the truth lies somewhere in middle. It has been argued in the present article that the interest of local and international actors have exacerbated the conflict in Laos. The internationalization of conflict in Laos between the two Geneva conferences of 
1954 and 1962 forms an important aspect in the history of international relations. During the cold war period, the problem of Laos was exacerbated due to strategic location of Laos and national interest of external actors. The present paper would endeavour to analyze various ramifications of conflict in Laos.

The landlocked country of Lao People's Democratic Republic has passed through vicissitudes of history facing problems like foreign invasion, external interference, and ideological conflict. Beginning from First Indochina War (1946-1954), fate of Laos was linked very closely with that of Vietnam. With the escalation of conflict, a solution to problem of Laos was nowhere in sight. The collapse of Dien Bien Phu on 7 May 1954 ended the French colonial rule. The Geneva Conference of 1954 did not solve the problem. The domestic politics of Laos revolved round three major actors; Pathet Lao, neutralists and the rightists. Externally, both the United States and North Vietnam came into conflict, as they were committed to help their respective allies in Laos, and regarded the other's action in Laos as harmful to their interest in South Vietnam. An agreement on Laos became contingent

(1) upon ending the war in Vietnam. The net result of outside intervention was prolongation of conflict in Laos. The gulf between the internal factions in Laos widened, and the freedom of choice was restricted for the belligerents in Laos. Problem of Laos remained unsolved and there was de facto partition of the country. The civil war soon became internationalized. Each side drew outside support, and the external support aggravated the conflict.

\section{Struggle for Independence}

During Second World War, the Japanese took control of Laos and declared its independence from the French colonial rule on March 9, 1945. After surrender of the Japanese, Phetsarat - established the independent Lao Issara (Free Laos) Government on September 1. New - avenues were opened for the Lao elite to chart out a course of independence. The Lao Issara was short-lived. The French began to re-conquer its colonial Empire of Indochina. Laos - $\quad$ was soon engulfed in the First Indochina War (1946-1954) and the French granted limited independence on July 19, 1949. The developments in Laos were viewed differently by political groups. The three major strands in Laos; Pathet Lao, neutralists and the rightists became a constant feature of Lao politics henceforth. The left leaning Pathet Lao (Land of Lao) vociferously opposed the French move, whereas Souvanna Phouma (1901-1984) joined the new Royal Lao Government (RLG) Government formed in February 1950. The term, Pathet Lao is generally used for the Communist movement of Laos that began in 1945 and continued until 1975, when whole of Laos became Communist. It fought along with the Viet Minh and Khmer Rouge in the First Indochina War against the French. The three communist factions of Indochina had formed the Viet-Khmer-Lao alliance on 11 March 1951. The collapse of Dien Bien Phu on 7 May, 1954 ended the French colonial rule in Indochina and the next day, the Indochinese session of Geneva Conference began.

The participants in the Geneva Conference were France, the United States, the Soviet Union, British, China, Cambodia, Laos and both the Vietnams. The Pathet Lao representative did 
not succeed in becoming a conference participant and it was not recognized as a resistance government. It received official status as "Pathet Lao Fighting Units" (Unites Combatants Pathet Lao, UCPL). There were six documents pertaining to Laos in 1954 Geneva Agreements. The Agreement on the Cessation of Hostilities in Laos provided that except for certain French instructors and garrisons, foreign forces should be withdrawn from Laos within 4 months. The Pathet Lao troops were to regroup in the provinces of Phong Saly and Sam Neua, pending a political settlement (Article 14). An International Commission for Supervision and Control (IOC) was to supervise the agreements with India (Chairperson), Poland and Canada as its member countries. By another declaration pertaining to Articles 4 and 5 of the final declaration, the RLG pledged that it would not enter into military alliances and would settle its disputes by peaceful means. But the Geneva Conference of 1954 did not solve the problem of Laos. There was formation of national union government after the signing of the Vientiane Agreements of 1956-1957 between the Pathet Lao and RLG. But the politics of the country turned towards extreme right. In December 1959, the military dominated Government of General Phoumi Nosavan (1920-1985) arrested the Pathet Lao members of the National Assembly. Laos was plunging towards a crisis during the cold war period. Peace became illusive and Laos was embroiled in the civil war of 1960s.

\section{Involvement of the United States}

The situation in Laos was exacerbated by involvement of external powers, which intensified the conflict. The actors involved viewed the situation in Laos from their standpoint. The crisis escalated or de-escalated according to interest of superpowers, great powers and the neighboring countries. The United States and the then North Vietnam were major actors in Lao scenario, developing a patron-client relationship with the RLG and the Pathet Lao respectively. The United States administration saw the situation as part of communist drive for world domination. Laos was included in the containment strategy as first line of defense against North Vietnam and China. The American Secretary of State, John Foster Dulles had called Laos as "outpost of free world"1 (Department of State Bulletin, 28 February 1955, p.332) and commented the day after Geneva Conference began:

Whether this can be stopped at this point, and whether Laos, Cambodia and southern part of Vietnam, Thailand, Malaya, and Indonesia can be kept out of Communist control depends very much on whether we can build a dike around the present loss. ${ }^{2}$ (Senate, Committee on Appropriation, Mutual Security Appropriation for 1955 (Washington, 1955).

Thailand also became a key factor in American involvement in Laos. Bangkok was judging the American commitment to it by the steps that Washington was taking against spread of Communism in $\operatorname{Laos}^{3}$ (Mishra, 1999). The United States supported the leaders of Laos, who would best serve its interest. It strengthened the RLG by massive military and economic aid. Laos became the only country of world, whose military budget was being supported by the United States cent percent. A special Protocol added Laos to be protected by the South East Asia Treaty Organization (SEATO) of September 6, 1954. The Military Advisory Assistance 
Group (MAAG) could not be sent to Laos under the terms of the Geneva agreements and therefore, a Program Evaluation Office (PEO) was established. It was a military mission staffed by the United States armed forces, whose military ranks were removed temporarily. ${ }^{4}$ (Heintges, 1962) The PEO also was controlling the 25,000 strong Royal Lao Army (RLA), which was receiving eighty percent of total American aid to Laos. It was the State Department, which was in favor of supporting the RLA's entire military budget and the Joint Chiefs of Staff was of the opinion that military considerations were not taken into account. ${ }^{5}$ (House of Representative, 1961) In the crisis of Laos, it would be seen afterwards that different departments of the United States Administration were not unanimous in opinion as to the policy to be followed. The Central Intelligence Agency (CIA) helped in the formation of a rightist grouping, Committee for Defense of National Interests (CDNI) on June 17, 1958 (Hilsman,1967). Its aim was combating communism in Laos and the CIA backed the rightist politician, General Phoumi. The CIA advisor John Hazey was very close to him. ${ }^{7}$ (Wise and Ross, 1964) On the other hand, the State Department was supporting Phoui Sananikone (1903-1983), the Premier of Laos. But the CIA found Phoumi more pliable and it along C with the PEO advised him to stage a coup. He also stage managed the elections of April 1960 and the CIA agents were distributing money to village chiefs at the time of elections ${ }^{8}$ ( Hilsman, 1967). The cooperation between the Governments of United States, Laos and Thailand was going on well. The American aid was passing through Thailand to land locked Laos and the United States had built three new airfields in north-eastern Thailand. Both Laos and Thailand were maintaining close economic and military cooperation under the auspices of SEATO. The United States was encouraging to develop close relations between Vientiane and Bangkok. Transport and communication facilities improved between two,

which was a part of the American sponsored communication network in Laos, Thailand and 1 South Vietnam. The United States also built up the clandestine army (Armee Clandestine, - AC) consisting of the Hmong (Meo) tribals and mercenaries from Thailand, Myanmar, - Cambodia and the Philippines. Thailand became a rear base for the American policy of containment of communism.

$\square$

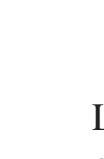

\section{North Vietnam and Laos}

Laos was strategically important to North Vietnam. The close collaboration between communist factions of the three Indochinese states began with the formation of the Indochinese Communist Party in 1930. The leader of the Pathet Lao, Prince Souphanuvong had met the Vietnamese Communist leader Ho Chi Minh in 1945 and gained control of central Laos with the help of Vietnamese troops. ${ }^{9}$ (Mishra, 1974) The Prince along with leaders like Kaysone Phomvihan, Phoumi Vongvichit, and Nouhak Phoumsavan had nurtured the Communist movement. Souphanouvong proclaimed the parallel Government of Pathet Lao along with its political organ, Neo Lao Issara (Lao Free Front) on August 13, 1950.10 (20 Years of Lao People's Revolutionary Struggle, 1966) Hanoi's goal was unification of Vietnam and Ho Chi Minh had proclaimed after the Geneva Conference of 1954 that it would be achieved..$^{11}$ (Statement by the President Ho Chi Chi Minh after the Geneva Conference, 1955) The northern provinces of Phong Saly and Sam Neua, controlled by the Pathet Lao 
were of immense help as Communist cadres could be sent to South Vietnam through these areas. The mountain terrain adjoining these provinces of Laos and North Vietnam were suitable for guerilla warfare also. North Vietnam reacted sharply to the formation of SEATO and the American aid to South Vietnam. An independent South Vietnam would not have survived without aid from Washington and that country was "essentially the creation of United States"12 (The Pentagon Papers, 1971). Hanoi had realized this fact and increased support to the Communist factions of Laos, Cambodia and South Vietnam. In December 1960, the National Liberation Front (NLF) of South Vietnam had come into existence and Laos became more closely interlinked in Hanoi's task for reunification.

Apart from giving material help to the Pathet Lao like supply of arms and training, Hanoi was playing an important role in its organizational structure. The Pathet Lao Army (PLA) was formed with the assistance from North Vietnam. As the war engulfed in Indochina in 1960s and 1970s, the PLA provided a supporting role to the North Vietnamese Army (NVA). Hanoi had a military mission in each of the Pathet Lao controlled provinces. There was presence of advisors from the NVA in Pathet Lao with six in each battalion, three in a company and two advisors in each platoon ${ }^{13}$ (Author's interview with Lt. Col. Chansamore Inthavong, 1977). The North Vietnamese also exerted a strong influence on the Phak Pasason Lao (People's Party of Laos) proclaimed on March 22, $1955^{14}$ (Langer and Zasloff, 1970). It was renamed the following year as the Lao People's Revolutionary Party (LPRP). Modelled closely after the Lao Dong party of North Vietnam, the LPRP also was controlling the broad based political organization, the Neo Lao Hak Sat (NLHS, Lao Patriotic Front) established on January 6, 1956. Many of the LPRP men had been members of the ICP. Kaysone was the Secretary General of the LPRP, which had a Central Committee of twenty members. In May 1959, Hanoi began to give more aid to the Pathet Lao after a decision by the Lao Dong party. It also began to increase assistance to the NLF and exerted strong influence on it after formation of the People's Revolutionary Party in January 1962.

\section{Crisis in Laos}

From 1960s, Lao crisis escalated and the country was plunged into a civil war. The 1962 Geneva Accords gave temporary respite to the country. The pattern of escalatory and deescalatory momentums continued until whole of Laos became Communist in 1975. Events moved fast in Laos after the coup of Captain Kong Lae of Second paratroop battalion on August 9, 1960. He was irked over the rampart corruption and American interference in Laos. The Pathet Lao leader Phoumi Vongvichit welcomed the coup as well as the establishment of a neutralist Government formed by Souvanna Phouma ${ }^{15}$ (Vongvichit, 1969). Both the rightist leaders like Phoumi Nosavan and Boun Oum were opposed to it. Boun had declared that Souvanna's Government was illegal and charged that it had opened Laos to North Vietnamese aggression ${ }^{16}$ ( New York Times, 1960). He declared himself the Premier of Laos. The situation in Laos became a three sided struggle and fighting soon broke out. To the left there was the Pathet Lao, Boun Oum-Phoumi Nosavan faction represented the right and in the center stood Souvanna with his neutralist followers. Upon internal quarrels, international 
rivalry was superimposed. The civil war became internationalized with each side drawing external support. The different branches of the American Government had conflicting policies towards development in Laos. Winthrop G. Brown, the new ambassador to Laos supported Souvanna. J. Graham Parsons, the former ambassador to Vientiane headed the Bureau of Far Eastern Affairs. He persuaded Souvanna to break off relations with the Pathet Lao and support Phoumi Nosavan. The American President Dwight David Eisenhower later on wrote that Parsons Mission was to break off with the Pathet Lao ${ }^{17}$ (Eisenhower, 1965). In October 1960, both the State and Defense Departments decided that Souvanna should go and suspended American aid to Laos. Faced with this and economic blockade by Thailand, Souvanna turned towards the Soviet $\operatorname{Union}^{18}$ (Schlesinger Jr.,1965).

Diplomatic Relations were established between Laos and the Soviet Union. Alexander N. Abramov became the first Soviet ambassador to Laos on October 13, 1960. On November 18 Souvanna and the Pathet Lao signed an agreement for formation of a coalition Government and establishment of diplomatic relations with North Vietnam and China. This was the period of the deteriorating relationship between the Soviet Union and China. Beijing had accused Moscow that it was not doing its duties to promote world revolutions. The Soviet leader Nikita Khrushchev had denied this. He wanted to have the support of North Vietnam in the Sino-Soviet rift. The Soviet Union did not want that they should be blamed by Hanoi of betraying national liberation movements. Hence it gave support to the Pathet Lao. Moscow also criticized vehemently against the American policy in Laos. On August 17,1959 , it had released a lengthy document on Laos, where it blamed the United States for giving military help to the RLG and interfering in internal affairs of Laos ${ }^{19}$ (Royal Institute of Internal Affairs, 1959). The document commented that neither North Vietnam nor China was sending military equipment and personnel to Laos. Moscow backed the Government of 1 Souvanna, which was being supported by the Pathet Lao. It began to supply rice and oil from December 4, 1960 and the Soviet planes arrived daily with these supplies ${ }^{20}$ (Lao Presse, - 1960). Afterwards the Soviet Union began supplying military aid to the neutralist-Pathet Lao faction. On 11-12 December, the Russian aircraft delivered three $105 \mathrm{~mm}$ howitzers, three heavy mortars and ammunition to Vientiane ${ }^{21}$ (Toye, 1968). The airlift to the strategic Plain of Jars became a top priority for the Soviet Union with 180 sorties to Laos in between December 15, 1960 and January 3, 1961 ${ }^{22}$ (Department of State Bulletin, 1961).

(1)

The Sino-Soviet rift was one of the major factors in determining the Chinese policy towards Laos. On April 16, 1960, the Chinese in an article entitled, Long Live Leninism, criticized the policy of peaceful coexistence and peaceful transition to socialism of $\mathrm{Khrushchev}^{23}$ (Peking Review, 1960). As China shared over three hundred and fifty kilometers border with Laos, it viewed with concern prospect of any foreign power having a foothold in Laos. Apart from expressing concern over American military aid to the RLG, Beijing criticized SEATO for its aggressive design over China and interference in internal affairs of Laos. Diplomatic relations were established with Laos. China supported the agreement of Souvanna with the Pathet Lao. On October 7, 1961, it established a consulate in Phong Saly and after a month, a cultural delegation visited Laos. The Chinese military journal, Kung-tso T' unghsun mentioned that the United States had supplied Phoumi $105 \mathrm{~mm}$ howitzers, M-24 tanks and Thai military personnel were training his troops ${ }^{24}$ (Cheng,1966). 
The Pathet Lao-neutralist Government was short lived as Phoumi's forces marched towards Vientiane in December 1960. He became the Defense Minister in the new Government and Boun Oum was the Premier. The subsequent defeat of Phoumi's forces raised the possibility of American intervention. The Administration of John F. Kennedy was confronted with the dilemma of intervening or not intervening. In an obvious warning to the Communist powers, the President ordered the Seventh Fleet to move into the Gulf of Thailand. At the SEATO Council meeting, it was declared that action might be taken unless the Pathet Lao agreed for a ceasefire $^{25}$ (Phuangkasem,1972).In the press conference of March 23,1961,Kennedy said that the United States preferred a neutralized Laos, but would not hesitate to intervene if necessary ${ }^{26}$ (Public papers, 1962). In the National Security Council meeting the question of sending American troops was discussed. But the Bay of Pigs invasion on Cuba of April 17 had made - Kennedy to remark, "If it hadn't been for Cuba, we might be about to intervene in Laos" 27 (Schlesinger Jr., 1965). Fearing that the adversaries would think him weak, the task force in Okinawa was put on alert. The Commander-in-Chief of Pacific Forces was ordered to move American combat brigades of 5,000 personnel each to north-east Thailand and South Vietnamese coast as "a threat to intervene in Laos" ${ }^{28}$ (The Pentagon Papers, 1971).

\section{Peace Process and Events of Nam Tha}

Attempts to bring an end to civil war were going on ${ }^{29}$ (Mishra, 1999). India as Chairperson of the International Commission for Supervision and Control (ICC) sent a message to Britain and the Soviet Union (Co-chairpersons) proposing reactivation of the ICC. ${ }^{30}$ It was agreed that an international conference would be convened in Geneva to end the crisis in Laos. The different factions in Laos were to observe ceasefire and send their representatives to Geneva. On May 16, 1961, the 14-nation conference began consisting the signatories of the 1954 Geneva Conference ( Great Britain, Cambodia, China, France, Laos, Soviet Union, United States and both the Vietnams), the members of the ICC, Thailand and Myanmar. The Soviet Union, United States and China sponsored Souvanna, Vientiane Government and the Pathet Lao respectively. It took more than a year for final agreement and peace efforts were punctuated by hostilities. The problem of ceasefire provoked heated debates with charges and counter-changes. In late May and early June 1961, a battle began around Ban Padong, about $10 \mathrm{kms}$ south of Plain of Jars. The Hmong tribes numbering about 9,000 were conducting guerilla operations against the Communists with help from the CIA chief of Vientiane ${ }^{31}$ (The Pentagon Papers,1971). Ban Padong was captured by 5, 00 Pathet Lao and the North Vietnamese soldiers. Much hue and cry was raised and the American delegation headed by Averell W. Harriman walked out of the conference, which was suspended for five days.

The situation improved after the Kennedy- Khrushchev meeting on June 3 and 4, 1961 in Vienna. It had a health effect on the course of events in Laos, albeit temporarily. Laos was the only area, on which there appeared some prospect of agreement in the summit meeting. Kennedy said:

The only area which afforded some immediate some prospect of accord was Laos. Both sides recognized the need to reduce the dangers in that situation. Both sided endorsed the 
concept of a neutral and independent Laos much in the manner of Burma or Cambodia. Of critical importance to the current conference on Laos in Geneva, both sides recognized the importance of an effective ceasefire ${ }^{32}$ (Schlesinger,1965).

Until the three factions of Laos agreed to form a coalition Government and cessation of hostilities, a settlement in Geneva was not feasible. Souvanna, Souphanouvong and Boun signed a communiqué in Zurich on 22 June in this regard. The declarations of Zurich were not followed with appropriate action and each faction began to build up their strength with fresh supplies. While the delegates in Geneva were preparing modalities of an agreement, the skirmishes continued, snowballing to the serious crisis of Nam Tha in 1962.

Phoumi's strategy was to continue the hostilities so that he would retain American support. Even he had announced that the Chinese and Russian troops were active in the area. The United States did not believe in these blatant lies and in January1962 stopped the cash grant of 4 million dollars so that Phoumi would yield ${ }^{33}$ ( New York Times, 1961). The President had appealed personally to Phouomi to merge the RLG under a tripartite coalition led by Souvanna. The CIA handler of Phoumi also was transferred from Laos. In February, the United States suspended the salary money that Phoumi used to pay every month to army. The American pressure was to bring Phoumi to agree for a coalition Government ${ }^{34}$ (Senate,1962). The cutting off aid went on for four months. But, the supply of military equipment continued, lest the Pathet Lao along with the neutralists take a stronger position.

Nam Tha, a strong hold of Phoumi was situated about $10 \mathrm{kms}$ from the Chinese and $125 \mathrm{kms}$ from Thai borders respectively. It served as a base for probing into the Pathet Lao territory and the hostilities intensified by end of April 1962. It was believed that the CIA had prodded CPhoumi to reinforce Nam Tha garrison. He believed that there would be policy difference in the United States administration as in 1960 and Phoumi could count on support of the CIA and Pentagon in opposing a coalition Government ${ }^{35}$ ( Hilsman, 1965). On May 6 Nam Tha
fell into the hands of the Pathet Lao and Phoumi's troops along with the Commander-infell into the hands of the Pathet Lao and Phoumi's troops along with the Commander-in-
Chief of the RLA crossed to Thailand. Alarmed by the events in Laos, Thailand had sent its troops to Nam province bordering Nam Tha. The Thai concern was motivated by security and anti-Communism ${ }^{36}$ ( Mishra, 1999). It wanted a friendly regime in Laos. Marshal Sarti Thanarat, the Thai Premier's hostility towards Pathet Lao was motivated by Communist phobia and he shared this with his close relative Phoumi. In the north-eastern Thailand, Communist insurgency had been on increase with support from other side of the border along with China and North Vietnam ${ }^{37}$ (South-East Asian Spectrum, 1973). Both the United States and Thailand signed the Rusk-Thanat agreement on March 6, 1962, which spelled out that obligations under SEATO were "individual as well as collective" 38 (Department of State Bulletin, 1962). The United States declared unilateral defense guarantee and military assistance to Thailand was doubled.

Alarmed at the Nam Tha developments, the United States took measures to deter the Communists for further advances. There were different opinions in the American administration regarding the course of events to be followed. The Pentagon, keen on preventing a coalition Government urged an all-out effort including a nuclear attack on 
China $^{39}$ (Hilsman, 1965). The State Department representing a political line advocated for a limited military intervention. The Seventh Fleet moved into the Gulf of Thailand on 12 May and two days later, 1,000 American soldiers moved to Udorn situated about $50 \mathrm{kms}$ from Lao border. The United States announced the dispatch of 5,000 troops to Thailand. Australia, Great Britain and New Zealand also sent token forces. Kennedy in a press conference of 17 May said that the purpose of sending troops was for ensuring Thailand's territorial integrity ${ }^{40}$ (Current Documents, 1966). The Pathet Lao troops did not violate ceasefire and the American soldiers did not cross the Mekong River. The crisis thus fizzled out.

On June 7, 1962, talks were resumed between the Lao leaders once again on the Plain of Jars. A coalition Government was to be formed with Souvanna as the Premier. Phoumi and Souphanouvong were to be Deputy Prime ministers. The delegates of Geneva Conference presented on 23 July two documents on Laos; a Declaration on the neutrality of Laos and a Protocol to $\mathrm{it}^{41}$ (Laos, 1967). The signatories pledged that they would not indulge in any manner affecting the sovereignty, independence, neutrality and territorial integrity of Laos. The introduction of foreign troops was prohibited and the ICC would supervise the ceasefire. The July 9 statement of the Lao coalition Government, pertaining to penkang or neutrality was also included in the Geneva Accords. It had proclaimed establishment of diplomatic relations with all countries and adherence to five principles of peaceful co-existence.

\section{Rapprochement between Different Actors}

The main participants of the crisis in Laos were on the brink of getting involved in a war, but they opted for a compromise. Behind the de-escalation, the considerations of major actors were obvious. By 1962, the strategic considerations of the Soviet Union and China over Laos were divergent. While the Soviet Union visualized Laos in the context of its relations with the United States, Beijing was following a policy of confrontation with the Washington. Khrushchev had strongly opposed a militant line on Indochina. In his speech of January 6, 1961, on wars of national Liberation, the Soviet leader had said that the Soviet Union was for peaceful co-existence ${ }^{42}$ (Communism-Peace and Happiness for the Peoples, 1963). The Communist countries would support national liberation, but should not internationalize it. In the crisis of Nam Tha, the Soviet Union did not interfere. It also asked the Pathet Lao to show a more flexible attitude for forming a coalition Government. The Soviet Union was interested more in the affairs of Europe. Its policy in Laos was to strengthen the bargaining position in Europe vis-à-vis the United States. The limited arms supply to Pathet Lao-neutralist alliance in 1960-1961 was more of an exception than a rule as will be evident from the Soviet policy after 1962 .

China supported the Pathet Lao as the victory of rightists would mean another pro- United States Government in its southern border. Suspicious of the Soviet Union's policy of peaceful coexistence and its reluctance to provide nuclear weapons, China was very much concerned about American military bases in Japan, Taiwan, South Korea and the Philippines. Yet, it could not risk a war with the United States. The weakness in economic front after the Great Leap Forward movement was another constraint. Hence, it was suggesting a dual policy 
in Laos; local military operations coupled with political negotiations. Going to the Geneva conference would be advantageous for it as Laos would be neutralized. The protective umbrella of SEATO also would be removed from Laos. Following the dual revolutionary tactics, 'Nam Tha' had to be followed by political negotiations. The military strategy had to be guided by political thinking in the People's War.

Laos was not worth risking a global war for the United States and it went to the Geneva Conference after its show of force in Nam Tha crisis had become successful The Communists responded to the ceasefire. Kennedy applied coercive diplomacy so as to halt the Pathet Lao advance. This type of diplomacy points towards "focusing enemy's will rather than upon negating his capabilities" ${ }^{43}$ (George, 1971). The United States wanted to gain time so that in future anit-Communist forces would conduct struggle from an advantageous position. As Roger Hilsman, the Director, Bureau of Intelligence and Research in administration of Kennedy had admitted: "We understood perfectly well that (it) was the starting gun...If we had used negotiations... as an excuse to withdraw from Laos... we in effect would have been turning it over to the communists"44 (Senate, 1965). The application of show of force was to stall an outright victory for the Pathet Lao. The United States favoured a political solution, at least for the time being. The Kennedy- Khrushchev meeting in Vienna was another factor for a comprise solution. The other reasons that might have influenced decision of Kennedy were: (i) The SEATO members were not unanimous in an outright intervention in Laos, (ii) The American embassy, especially its ambassador, Brown, believed that a compromise formula was the best course of option and (iii) Increase in Viet Cong activities in South Vietnam required more troops and attention of the United States.

North Vietnam and the Pathet Lao also agreed for de-escalating the crisis. Hanoi had seen that the Pathet Lao had increased it strength as compared to the time of Geneva Conference - of 1954; numerically as well as territorially. It had become easier to send cadres to South Vietnam through north eastern provinces of Laos, which were controlled by the Pathet Lao. The landing of American troops in Thailand, Soviet pressure, political gain in a conference - table and lack of resources to occupy whole of Laos were factors responsible for coming to Geneva talks. The Pathet Lao had changed its tactics from armed insurrection to national front as it did at the time of Geneva conference of 1954 and 1956-1957 Vientiane agreements.

Two basic and three preliminary conditions are parameters for a negotiated solution 45 (Modelski, 1964) and all these were there in the Lao situation of 1960-1962 ${ }^{46}$ (Goldstein, 1973). The basic conditions are stalemate and redistribution of aims. Stalemate in the battlefield was restored, when the United States sent its troops in Nam Tha crisis and the Pathet Lao agreed to negotiate. It was to the middle faction of neutralists that both the rightists and Communists made concessions. Souvanna was acceptable to both and distribution of portfolios was easier. The three basic conditions were identity of parties, duration of conflict and existence of contact between the parties. In Lao scenario, identity of parties was well known. The conflict between the rightists and Pathet Lao was of long duration and quick victory was unlikely. The channel of communication was open due to meeting of the factions and presence of ICC. 


\section{Conclusion}

The coalition Government that was formed after the Geneva Accords of 1962 functioned smoothly in the beginning with the three factions: left, neutrals and the right cooperating with each other. However, the troika or three-pronged administrative structure did not last long. Souvanna Phouma became Premier with charge of defense. Souphanouvong and Phoumi Nosavan, both the Deputy Premiers represented the left and rightist groups respectively. All decisions of the Government were to be taken in accordance with unanimity rule. Such an arrangement was doomed from the beginning. The wrangling over distribution of foreign aid began and each side endeavored to channel maximum to its own faction. They also kept control of its military forces. Mutual suspicion of among the three groups prevented the smooth functioning of the Government. There was also a split in the neutralist camp after a series of assassinations in the capital Vientiane. In politics of Laos henceforth witnessed two strands, the rightists and leftists with neutralist joining either faction. Though Souvanna wanted national reconciliation, he did not want Pathet Lao to play a dominant role. He gradually drifted away from the Pathet Lao and moved towards right. The military Generals began to assume real power and he remained a 'symbolic' figure. By 1964, three pronged administrative structure had become defunct and situation in Laos returned to pre-1962 situation. The tripartite meeting of Souvanna, Souphanouvong and Phoumi Nosavan in September 1964 at Paris failed. Hostilities were resumed and some of the signatories of the Geneva Accords observed the provisions by violating it.

Laos was became a 'side show' of the Vietnam War. The two major actors, the United States and North Vietnam followed policies in Laos keeping in mind the compulsions of the War. The escalation of the Vietnam War aggravated the conflict in Laos and Washington as well as Hanoi became deeply involved in the affairs of Laos. The problem of Laos remained unsolved and there was de facto balkanization of the country. A solution to Lao conflict was in sight after the Geneva accords of 1962. However, the gradual linkage of the country with the Vietnam War made the solution of conflict dependent upon the outcome of conflict in Vietnam. However, whole of Indochina became red after the end of Vietnam War. 


\section{End Notes}

2

Senate, Committee on Appropriation, Mutual Security Appropriation for 1955 (Washington, 1955), Hearings, Cong.83, Sess.2, 1954, p.305.

Patit Paban Mishra, A Contemporary History of Laos. (New Delhi: National Book Organization, 1999), p. 49.

General John A. Heintges, Chief of the PEO in between 1958 and 1961 called it as a similar organization like MAAG. See, Senate, Committee on Armed Services, Military Cold War Education and Speech Review Politics, Hearings before the Special Preparedness Subcommittee, part 5, Cong. 87, Sess. 2, 1962 ( Washington, 1962), p.2371. The American Senator Silvio O. Conte, who visited Laos in 1959, commented that the staffs of PEO were ex-marines and army men. House of Representative, Committee on Appropriations, Operations Appropriations for 1962, Cong. 87, Sess. 1, 1961 ( Washington, 1961), p.589.

House of Representatives, Committee on Government Operations, U.S. Aid Operations in Laos, Seventh Report, Cong.86, Sess. 1, 1959 (Washington, 1959), pp. 45-46.

Roger Hilsman, To Move a Nation: The Politics of Foreign Policy in the Administration of John F. Kennedy (Garden City, 1967), p.115.

David Wise and Thomas B. Ross, The Invisible Government (New York, 1964), p.173.

Hilsman, n. 6, p.122.

For details pertaining to the formation of the Pathet Lao, See, Patit Paban Mishra, " The Pathet Lao Movement" ( M.Phil. thesis, Jawaharlal Nehru University, School of International Studies, New Delhi, 1974).

20 Years of Lao People's Revolutionary Struggle (Neo Lao Hak Sat Publications, n. p., 1966), p.11.

Statement by the President Ho Chi Chi Minh after the Geneva Conference (Hanoi, Foreign Language Publishing House, 1955), pp.3-7.

12 The Pentagon Papers, as published by the New York Times (New York, 1971), p. 25.

13

Author's interview with Lt. Col. Chansamore Inthavong at Nong Khai refugee camp, Thailand, May 28, 1977.

14 Paul F. Langer and Joseph J. Zasloff, North Vietnam and the Pathet Lao: Partners in the Struggle for Laos (Cambridge: Harvard University Press, 1970), p.92.

15 Phoumi Vongvichit, Laos and the Victorious Struggle of the Lao People against U.S. NeoColonialism (NLHS publications, n.p., 1969), p.126. 
口

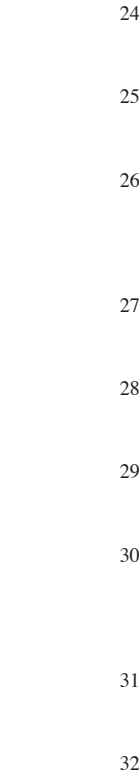

32

Department of State Bulletin, June 26, 196, p.993. Khrushchev had told Kennedy in Vienna that the Soviet Union had "no desire to assume responsibility in remote geographical area." See, Schlesinger, n.18, p.333.

New York Times, September 12, 1960.

Dwight D. Eisenhower, Waging Peace (Garden City, 1965), p.608. He was the President of the US in between 1953 and 1961.

Arthur M. Schlesinger Jr., A Thousand Days: John F. Kennedy in the White House (Boston, 1965), p.303.

For the full text, see, Royal Institute of Internal Affairs, Document on International Affairs, 1959 (London, 1959), pp, 261-265.

Lao Presse, November 25 and December 5, 1960.

Hugh Toye, Laos: Buffer State or Battleground (London, 1968), p.159.

Department of State Bulletin (Washington, January 23, 1961), pp. 114-115.

For details see, Peking Review, no.17, April 26, 1960, pp. 6-23.

J. Chester Cheng, ed., The Politics of Chinese Red Army (Stanford, 1966), p.336.

P.C. Phuangkasem, Thailand and SEATO (Bangkok, 1972), p.34.

Public Papers of the President of the United States, John F. Kennedy, 1961 (Washington, 1962), pp, 213-218.

Schlesinger Jr.n. 18, p.316.

The Pentagon Papers, n.12, p. 89.

For details see, Mishra, n.3, pp, 71-75.

The ICC was formed after the Geneva Conference of 1954 to supervise the agreements. Poland and Canada were the two members.

The Pentagon Papers, n.12, pp, 134-135.

New York Times, January 16, 1961.

Hariman said that the salary money was stopped as the Vientiane Government was not "negotiating in good faith for a coalition government." See, Senate, Committee on Foreign Relations, Foreign Assistance Act of 1962. Cong. 87, Sess. 2, 1962 (Washington, 1962), p.369. 
35 Hilsman, n. 6 , p. 138.

36 For details see, Mishra, n. 3, pp, 81-83.

37 "Communist Insurgency in Thailand" (Unofficial Summary of the Government White Paper), South-East Asian Spectrum, vol.1 1, no. 4, July 1973, p.33. A separatist movement also was there in north-eastern Thailand, whose goal was creation of a neutral Laos.

Department of State Bulletin, March 26, 1962, p.499.

Hilsman, n. 6, p. 142.

Department of State, American Foreign Policy: Current Documents, 1962 (Washington, 1966), p. 1094.

For the text, see, UK, Central Office of Information, Laos (London, 1967), pp. 50-55.

Communism- Peace and Happiness for the Peoples, January-September 1961 (Moscow, 1963), vol.1, pp. 389-391.

Alexander L. George and others, The Limits of Coercive Diplomacy (Boston, 1971), p. 18.

Senate, Committee on Judiciary, Refugee Problem in South Vietnam and Laos. Cong. 89, Sess. 1, (Washington, 1965), p.328.

George Modelski, "International Settlement of Internal War", in James N. Rosenau, ed., International Civil Strife (Princeton, 1964), p. 143.

Martin E. Goldstein, American Policy Toward Laos (Cranbury, 1973), pp. 283-285. 


\section{References}

Cheng, J. Chester. (Ed.) (1966). The politics of Chinese Red Army. Stanford: Stanford university Press.

Chomsky, Noam. (1970). At war with Asia. New York: Vintage Books.

No desire to assume responbility in remote geographical area. (1964, June 26). Department of State Bulletin

Dommen, Arthur J. (1971). Conflict in Laos: The politics of neutralization. New York: Praeger, rev. edn.

Goldstein, Martin E. (1973). American policy towards Laos. Cranbury: Associated University Presses.

Hilsman, Roger. (1967). To move a nation: The politics offoreign policy in the administration of John P. Kannedy. Garden City: Doubleday.

Kaiser, David. (2000). American tragedy: Kennedy, Johnson and the origins of the Vietnam War. Cambridge: MA: Harvard University Press.

Langer, Paul F. \& Joseph J. Zasloff. (1970). North Vietnam and the Pathet Lao: Partners in the struggle for Laos. Cambridge/Mass, Havard University Press.

Laos, Ministry of Information. (1972). Nixon's intensified special war in Laos. Publisher and Place Name not on the book.

Mishra, Patit Paban. (1999). The contemporary history of Laos. New Delhi: National Book Organization.

Mishra, Patit Paban. (1984). Laos: Land and Its People. Indian Centre for Studies on IndoChina.

Mishra, Patit Paban. (1974). The pathet Lao movement. (unpublished M.Phil thesis). Jawaharlal Nehru University, School of International Studies, New Delhi.

Modelski, George A. (1962). International Conference on the Settlement of the Laotian Question, 1961-62. Canberra: Australian National University.

(1961, January 16). New York Times

Phoumi Vongvichit. (1969). Laos and the victorious struggle of the Lao people against U.S. Neo-Colonialism. NLHS publications, n.p. 
P.C. Phuangkasem. (1972). Thailand and SEATO. Bangkok: Thai Watana Panich.

Public Papers of the President of the United States, John F. Kennedy, 1961.(1962). Washington: Government Printing Press.

Senate, Committee on Armed Services. (1962). Military cold war education and speech review politics. Washington: Government Printing Press.

Schlesinger, Arthur M. Jr. (1965) A Thousand Days: John F. Kennedy in the White House. Boston, Houghton Mifflin.

The Pentagon Papers. (1971). New York: New York Times.

Toye, Hugh. (1965). Laos : Buffer state or battleground. London: Oxford University Press.

C Vatthana Pholsena. (2006). Post-war Laos: The politics of culture, history and identity. - Singapore: ISEAS publications. 